PRZEGLĄD NAUK HISTORYCZNYCH 2018, R. XVII, NR 1

http://dx.doi.org/10.18778/1644-857X.17.01.01

ARTYKUEY, STUDIA I ROZPRAWY

ZBigniew ANusiK

UNIWERSYTET ŁÓDZKI

\title{
Podzial latyfundium Eustachego i Marianny z Kątskich Potockich w 1771 roku
}

Streszczenie. Artykuł poświęcony jest procesowi formowania się latyfundium, które znalazło się w posiadaniu Eustachego Potockiego i jego żony Marianny z Kątskich. Jego twórcą był podkanclerzy litewski Stanisław Antoni Szczuka (zm. 1710). W skład omawianego kompleksu majątkowego weszły też dobra, które były własnościa Marcina (zm. 1710) i Jana Stanisława (zm. 1727) Kątskich oraz Jerzego Potockiego (zm. 1747). Eustachy i Marianna Potoccy byli właścicielami łącznie 11 miast, ponad 100 wsi i 25 folwarków. Dobra te przynosiły 460 tys. złp. rocznego dochodu. Po śmierci obojga małżonków w lutym 1768 r. ich latyfundium zostało podzielone między ich pięciu synów. Akt podziałowy został spisany w Warszawie w listopadzie $1771 \mathrm{r}$. Na każdego ze spadkobierców przypadły dobra przynoszace ok. 80 tys. złp. dochodu rocznego netto. Podział dawnego latyfundium Eustachego i Marianny Potockich sprawił, że ich synowie spadli do rzędu uboższych członków rodziny Potockich.

Słowa kluczowe: latyfundia, rodzina Potockich, magnateria polska XVIII w., podział dóbr Eustachego i Marianny Potockich.

$\mathrm{E}$ ustachy Potocki (1719-1768) był potomkiem potężnego i bardzo wpływowego w XVIII stuleciu rodu Potockich herbu Pilawa. Urodził się jako najstarszy syn Jerzego (zm. 1747), starosty grabowieckiego i tłumackiego, oraz jego drugiej żony, Konstancji z Druckich-Podbereskich (zm. 1730), marszałkówny upickiej, wdowy po staroście bolimowskim Marcinie Leopoldzie Zamoyskim. Pochodził ze starej rodziny magnackiej o ugruntowanych tradycjach senatorskich. Co prawda, jego ojciec nie zasiadał w senacie,

* Wydział Filozoficzno-Historyczny, Instytut Historii, Katedra Historii Nowożytnej, e-mail: zanusik@uni.lodz.pl. 
ale dość wspomnieć, że dziadkami Eustachego byli Feliks Kazimierz Potocki (zm. 1702), kasztelan krakowski i hetman wielki koronny, oraz Krystyna $z$ Lubomirskich, córka rokoszanina Jerzego. Senatorami byli również dwaj starsi bracia jego ojca, nie wspominając już o pradziadach Eustachego - Stanisławie „Rewerze” Potockim (1589-1667), wojewodzie krakowskim i hetmanie wielkim koronnym, oraz Jerzym Sebastianie Lubomirskim (1616-1667), marszałku wielkim i hetmanie polnym koronnym ${ }^{1}$. Te znakomite parantele nie przekładały się jednak na pozycję majątkową rodziny Eustachego. Jego ojciec Jerzy, najmłodszy syn Feliksa Kazimierza i Krystyny $z$ Lubomirskich, odziedziczył po rodzicach jedynie klucz podhajecki w ziemi halickiej. Był też właścicielem majątku Syrniki (dziś Serniki) z przyległościami w województwie lubelskim, który kupił od Drohojowskich, oraz niewielkiego klucza horodyskiego w województwie brzesko-litewskim, który sprzedał mu jego brat stryjeczny Józef Potocki (zm. 1751). Z pewnościa posiadał też wsie Palaicze, Łokutka i Susz w ziemi halickiej, które sąsiadowały z trzymanym przez niego starostwem tłumackim. Po bezpotomnej śmierci brata Stanisława (zm. 1732), wojewody bełskiego, Jerzy Potocki wystapił $z$ roszczeniami do części spadku po nim (chodziło głównie o dobra Tartaków w województwie bełskim). Ostatecznie jednak zawarł ugodę $z$ bratankiem Franciszkiem Salezym, który jako główny spadkobierca wojewody zatrzymał te dobra w swoim ręku².

${ }^{1}$ Ojciec Eustachego - Jerzy Potocki po raz pierwszy ożenił się z Marianna Liniewską, kasztelanką wołyńska, z którą miał córkę Joannę, wydaną za Stanisława Wincentego Jabłonowskiego, wojewodę ruskiego. Po raz drugi ożenił się z Konstancją $z$ Druckich-Podbereskich i miał z nia, oprócz Eustachego, jeszcze trójkę dzieci: Mariana, Pelagię i Katarzynę. Por. S.K. Kos s akows ki, Monografie historyczno-genealogiczne niektórych rodzin polskich, t. II, Warszawa 1860, s. 210; T. Żychlińs ki, Złota księga szlachty polskiej, t. I, Poznań 1879, tabl. 3; S. U ru ski, A.A. Kosiński, A. Włodarski, Rodzina. Herbarz szlachty polskiej, t. XIV, Warszawa 1917, s. 291-292; W. Dworzaczek, Genealogia, t. II (Tablice), Warszawa 1959, tabl. 141. Por. też A. Przyboś, Potocki Feliks Kazimierz, [w:] Polski słownik biograficzny [dalej: PSB], t. XXVII, s. 807-812; oraz i d e m, Potocki Stanisław zwany Rewera, [w:] ibidem, t. XXVIII, Wrocław 1984-1985, s. 140-151. Starszymi synami Feliksa Kazimierza Potockiego i braćmi Jerzego, starosty grabowieckiego, byli natomiast: Michał (zm. 1749), wojewoda wołyński, Józef Felicjan (zm. 1723), strażnik wielki koronny i Stanisław Władysław (zm. 1732), wojewoda bełski. Więcej informacji na ich temat por. A. Li n k-Le n c z ow s ki, Potocki Józef Felicjan, [w:] PSB, t. XXVIII, s. 58-59; A. Link-Lenczows ki, E. Szklarska, Potocki Michat, [w:] ibidem, s. 97-101; A. Link-Le nczowski, Potocki Stanisław Władysław, [w:] ibidem, s. 154-156.

${ }^{2}$ Por. K. Niesiecki, Herbarz polski, wyd. J.N. Bobrowicz, t. VII, Lipsk 1841, s. 447; T. De mid owicz, Horodyszcze-zarys dziejów, Biała Podlaska 1996, s. 4; 
Być może miał jeszcze Jerzy Potocki kilka pojedynczych wiosek w innych częściach kraju, ale łączna wielkość jego dóbr alodialnych znacznie ustępowała nawet przeciętnym fortunom magnackim i sytuowała go co najwyżej w grupie zamożnej szlachty.

Dobra dziedziczne stanowiły jedynie część majątku, jakim dysponował Jerzy Potocki. Poważnym uzupełnieniem jego fortuny były majętności po Marcinie Zamoyskim, które znalazły się w dożywotnim użytkowaniu jego drugiej żony - Konstancji z Druckich-Podbereskich. Po jej śmierci w 1730 r. dobra te wróciły jednak w następnych latach do rodziny Zamoyskich ${ }^{3}$. Podobnie jak wielu innych przedstawicieli swojego rodu był też Jerzy Potocki dzierżawcą licznych królewszczyzn. W jego posiadaniu znalazły się starostwa tłumackie, grabowieckie, rostockie, dubieńskie, sannickie i tarnawackie $e^{4}$. Dzierżawił także, nadawane na podstawie osobnych

Archiwum Główne Akt Dawnych w Warszawie [dalej: AGAD], Archiwum Potockich z Radzynia [dalej: APR], nr 26 (Akta majątkowe Jerzego Potockiego dotyczące dóbr Tartaków); nr 33 (Akta procesu Jerzego Potockiego i jego synów z Janem Jakubem Zamoyskim o dobra Syrniki w powiecie lubelskim); nr 34 (Akta majątkowe Jerzego Potockiego i jego żony Marii z Liniewskich dotyczące dóbr Podhajce); Zbiór Aleksandra Czołowskiego, sygn. 643 (Dekret w procesie o dobra Syrniki między spadkobiercami Andrzeja Drohojowskiego, kasztelana łukowskiego, a Jerzym Potockim, starostą tłumackim i Suchodolskimi).

${ }^{3}$ Konstancja $z$ Druckich-Podbereskich $1^{\circ}$ v. Zamoyska $2^{\circ}$ v. Potocka trzymała w dożywociu po pierwszym mężu dobra Kutno w ziemi gostynińskiej, połowę miasta i włości Tarnów w powiecie pilzneńskim oraz majętność Ładyżyn w województwie bracławskim. Ten ostatni majątek należał formalnie do Józefa Potockiego (zm. 1751), ale faktycznie pozostawał (zapewne jako zastaw) w posiadaniu Marcina Leopolda Zamoyskiego, a następnie wdowy po nim. Por. M. Ko bi e re cki, Dzieje Kutna i okolicznych wsi w XVII i XVIII wieku, [w:] Kutno poprzez wieki, t. I (Do 1939 roku), red. J. Szymczak, Kutno-Łódź 2011, s. 182; AGAD, APR nr 19 (Akta procesowe Jerzego i Konstancji Potockich o zbiegłych poddanych z Ładyżyna); nr 25 (Akta procesowe Jerzego Potockiego przeciwko Zamoyskim, Stadnickiemu i Kotowskiemu w związku z posiadaniem połowy miasta i dóbr Tarnów); nr 153 (Akta procesowe Eustachego Potockiego z Zamoyskimi o pretensje do dóbr Kutno, będacych w posiadaniu jego matki, z pierwszego małżeństwa Marcinowej Zamoyskiej); nr 154 (Akta Eustachego Potockiego dotyczące dóbr Ładyżyn, Ulanów nad Bohem oraz Tarnów, na których zabezpieczono spadek po Marcinie Zamoyskim); nr 155 (Akta procesowe Eustachego i Mariana Potockich dotyczace ich pretensji własności do połowy miasta Tarnów z przyległościami). Dodajmy także, że druga żona Jerzego Potockiego zgłaszała również pretensje do szeregu innych dóbr należących do rodziny jej pierwszego męża.

${ }^{4}$ Por. K. Niesiecki, op. cit., t. VII, s. 447; A. Przyboś, Potocki Feliks..., s. 812; W. Dworzaczek, op. cit., t. II, tabl. 141; AGAD, APR nr 12 (Akta dotyczace posiadania starostwa rostockiego "powiat chełmski” przez Butlerów, Zamoyskich i Jerzego Potockiego); nr 13 (Akta kolejnych cesji starostwa grabowieckiego 
przywilejów, wsie królewskie Chorobów, Baranie Peretoki i Olchówka w powiecie bełskim, Osieków w województwie wołyńskim oraz Chreptyjów, Dziurdzianka i Dankowce w powiecie kamienieckim na Podolu 5 .

Zdając sobie sprawę $z$ tego, jak bardzo użytkowane przez niego królewszczyzny wpływaja na sytuację materialna rodziny, Jerzy Potocki stopniowo cedował posiadane przez siebie dobra domeny na swojego najstarszego syna. Jeszcze w dzieciństwie został on starostą dubieńskim (Dubienka nad Bugiem w powiecie horodelskim). W 1738 r. ojciec scedował mu natomiast starostwo tłumackie w ziemi halickiej oraz wsie Chreptyjów, Dziurdzianki i Dankowce na Podolu ${ }^{6}$. Dobra te mogły stanowić punkt wyjścia do przyszłej kariery Eustachego, ale nie mogły rzecz jasna równać się z jakąkolwiek fortuna magnacką. Już wkrótce jednak Eustachy Potocki dołączyć miał do grona najzamożniejszych magnatów koronnych. Ten niebywały awans majątkowy zawdzięczał małżeństwu $z$ bogatą jedynaczka - Marianna Katską herbu Brochwicz (1722-1768), która poślubił w Lublinie 26 grudnia $1741 \mathrm{r}^{7}$ Była ona córką Jana Stanisława Katskiego (zm. 1727), generała artylerii i miecznika koronnego, oraz Wiktorii ze Szczuków herbu Grabie (1701-1735), podkanclerzanki litewskiej. Jej dziadkami byli Marcin Katski (1636-1710), sławny generał artylerii $z$ czasów panowania Jana III Sobieskiego, który z czasem osiagnął kasztelanię krakowska, i nie mniej sławny Stanisław Antoni Szczuka (ok. 1654-1710), podkanclerzy litewski, autor traktatu politycznego Eclipsis Poloniae orbi publico demonstrata ${ }^{8}$.

i akta gospodarcze tegoż); nr 15 (Akta procesowe Jerzego Potockiego i Zdzisława Zamoyskiego o zbiegłych poddanych z ordynacji Zamoyskich do królewszczyzny Tarnawatka); nr 35 (Akta Jerzego i Marii z Liniewskich Potockich, dotyczące królewszczyzny Sanniki z przyległościami „ziemia gostyńska”); nr 163 (Akta Eustachego Potockiego dotyczące królewszczyzny Dubienka).

${ }^{5}$ Por. T. Żychliński, op. cit., t. XIV, Poznań 1892, s. 62; AGAD, APR nr 14 (Akta Jerzego Potockiego, starosty tłumackiego, dotyczące królewszczyzny Chorobów, Baranie Peretoki i Olchówek „powiat bełski”); nr 37 (Kwity uiszczonej kwarty z królewszczyzny Osieków przez Jerzego Potockiego z żoną, Marią z Liniewskich „województwo wołyńskie”).

${ }^{6}$ Por. T. Żychliński, op. cit., t. XIV, s. 62; B. Grosfeld, Potocki Eustachy, [w:] PSB, t. XXVII, s. 804.

7 Por. B. Gros feld, op. cit., s. 804.

8 Więcej informacji o rodzicach i dziadkach Marianny z Kątskich Potockiej por. E. Rabowicz, P. Stok, Kątski Jan Stanisław, [w:] PSB, t. XII, Wrocław-Warszawa-Kraków 1967-1968, s. 314-315; A. Przybós, Kątski (Kacki, Kontski) Marcin Kazimierz, [w:] ibidem, s. 316-319; H. Palkij, Szczuka Stanisław Antoni, [w:] ibidem, t. XLVII, Warszawa-Kraków 2010-2011, s. 469-481. 
Na dobra posagowe żony Eustachego Potockiego składały się przede wszystkim majątki jej dziadka macierzystego, Stanisława Antoniego Szczuki, który będąc potomkiem niezbyt zamożnej rodziny szlacheckiej, u schyłku życia dysponował już dobrami tworzacymi prawdziwie magnacka fortunę . Warto dodać, że ożeniony $z$ Konstancją Potocka (zm. 1733) z litewskiej gałęzi tego rodu, miał z nią Szczuka synów Marcina (zm. 1728), starostę wąwolnickiego, i Jana Kantego (zm. 1724), starostę wiekszniańskiego, oraz córkę Wiktorię, która w 1719 r. poślubiła Jana Stanisława Kątskiego, a owdowiawszy, w 1731 r. wyszła ponownie za mąż za kuchmistrza koronnego Jana Cetnera (zm. 1734). Bezpotomna śmierć braci sprawiła, że to Wiktoria Szczuczanka, matka Marianny z Katskich Potockiej, odziedziczyła cały wielki majątek, który po jej śmierci przeszedł na jej jedyna córkę ${ }^{10}$.

Marianna Kątska była też dziedziczką dóbr ziemskich należących do jej przodków po mieczu. Jej ojciec - Jan Stanisław Kątski był bowiem jedynym synem kasztelana krakowskiego Marcina i Urszuli $z$ Denhoffów, córki Teodora, podkomorzego koronnego i Katarzyny von Bessen. Po śmierci Marcina Kątskiego przejął wszystkie należące do niego majątki, które następnie odziedziczyła jedynaczka. Warto jednak zaznaczyć, że dobra po Kątskich stanowiły jedynie niewielką część fortuny wniesionej przez ich spadkobierczynię do domu Potockich ${ }^{11}$.

9 Stanisław Antoni Szczuka swoje wyniesienie zawdzięczał Janowi III Sobieskiemu. Otrzymał nadania królewskie (również od Augusta II i Stanisława Leszczyńskiego) na kilkanaście intratnych królewszczyzn. Przeprowadził wiele udanych operacji pieniężnych i systematycznie powiększał swoje dobra dziedziczne. W ziemi wiskiej stworzył kompleks dóbr z głównym ośrodkiem w założonym przez siebie mieście Szczuczynie. Przed 1686 r. otrzymał na własność dawną królewszczyznę - klucz radzyński w województwie lubelskim. W 1693 r. zagarnał dobra po zmarłym bezpotomnie stolniku wyszogrodzkim Adamie Kotowskim. Za niewielkie pieniądze wykupił prawa po spadku po nim od jego braci - Macieja, Michała i Wojciecha Kotów (chłopów pańszczyźnianych spod Kluczborka), nieświadomych rzeczywistej wartości pozostawionego przez Kotowskiego majatku. Pozyskał w ten sposób klucz kurowski w województwie lubelskim, pałac w Warszawie, cenne ruchomości oraz 86 tys. złp. w gotówce. W 1697 r. kupił Wysokie Mazowieckie w powiecie drohickim na Podlasiu. Żona wniosła mu Sidrę $z$ przyległościami w województwie trockim. Skupował też na korzystnych warunkach inne dobra - o czym niżej w tekście. Por. H. Palkij, op. cit., s. 470-477; A. Keckowa, Kotowski (pierwotne nazwisko Kot) Adam, [w:] PSB, t. XIV, Wrocław-Warszawa-Kraków 1968-1969, s. 482.

${ }_{10}$ Por. H. Palkij, op. cit., s. 478; W. Konopczyński, Cetner Jan, [w:] PSB, t. III, Kraków 1937, s. 240.

${ }^{11}$ Adam Przyboś, autor biogramu Marcina Kątskiego w PSB, podaje, że był on m.in. właścicielem dóbr Czerników, Komarów, Jemielno, Kozice, Krzywcze i Droz- 
Dodajmy także, że wobec dość wczesnej śmierci rodziców - ojciec zmarł w 1727, a matka w 1735 r. - nieletnia Marianna Kątska znalazła się pod opieką dalszych krewnych. Początkowo jej opiekunem został wojewoda podolski Stefan Humiecki (zm. 1736), siostrzeniec jej dziadka Marcina. Później trafiła pod kuratelę swojego brata ciotecznego Joachima Potockiego (zm. 1764), starosty lwowskiego, który był synem rodzonej siostry jej ojca - Teresy z Kątskich (zm. 1746), żony Stefana Potockiego (zm. 1730), marszałka nadwornego koronnego ${ }^{12}$. Nie ulega wattpliwości, że (dość odległe co prawda) pokrewieństwo $z$ opiekunem bogatej dziedziczki ułatwiło Potockim sfinalizowanie negocjacji o jej rękę.

Warto dodać, że Marianna Kątska wniosła swojemu mężowi nie tylko znaczne dobra ziemskie, lecz także prawa do kilku królewszczyzn. W pierwszym rzędzie były to starostwa urzędowskie w województwie lubelskim i korytnickie w województwie mazowieckim, które były obciążone sumami pożyczonymi Rzeczypospolitej przez jej przodków. Wkrótce po ślubie małżonkowie Potoccy uzyskali też ius communicativum na wspomniane tu dobra domeny ${ }^{13} . \mathrm{Z}$ bie-

dowice. Por. idem, Kątski (Kącki..., s. 318. Spośród wymienionych tu posiadłości jedynie dwie ostatnie zostały odnotowane w przyszłości jako własność Eustachego i Marianny z Kątskich Potockich. Dodajmy jednak, że w spadku po Kątskich objęli też Potoccy najpewniej cztery wsie na Podolu oraz klucz budzanowski i kilka wsi w województwie ruskim.

12 Por. E. Rabowicz, P. Stok, op. cit., s. 315; J. Gierowski, Humiecki Stefan, [w:] PSB, t. X, Wrocław-Warszawa-Kraków 1962-1964, s. 100-102; H. Dy mnicka-Wołoszyńska, Potocki Joachim, [w:] ibidem, t. XXVIII, s. 50-51. W tym miejscu należy sprostować błąd tej autorki, która podała, że Joachim Potocki był synem Stefana Potockiego i jego drugiej żony, Konstancji z Denhoffów. W rzeczywistości bowiem Potocki był synem trzeciej żony swojego ojca - Teresy z Katskich. Właśnie dlatego, że $z$ Marianną Kątska łączyło go bliskie pokrewieństwo, mógł zostać jej opiekunem. Por. też AGAD, APR, nr 169 (Akta Joachima Potockiego, starosty lwowskiego jako opiekuna małoletniej Marianny Kątskiej, dotyczące królewszczyzn Bieleckie al. Kalińce i Buchny „powiat latyczowski”).

${ }^{13} \mathrm{Na}$ starostwie urzędowskim (miasto Urzędów, wsie Dzierzkowice i Księżomierz) zabezpieczona była pożyczka w kwocie 50 tys. florenów, jakiej w $1663 \mathrm{r}$. udzielił Rzeczypospolitej pradziad Marianny z Kątskich Potockiej - podkomorzy koronny Teodor Denhoff. Miała ona zostać spłacona przez „wytrzymanie” czterech dożywoci przez spadkobierców podkomorzego. Po śmierci Teodora Denhoffa użytkownikami starostwa byli kolejni jego potomkowie: syn Henryk, córka Urszula (z mężem Marcinem Kątskim), wnuk Jan Stanisław Kątski (z żoną Wiktorią ze Szczuków) i wreszcie prawnuczka Marianna Kątska (z mężem Eustachym Potockim). W czasie lustracji starostwa urzędowskiego przeprowadzonej w 1765 r. uznano, że jego ówcześni użytkownicy - Eustachy i Marianna Potoccy, wobec 
giem czasu Eustachy Potocki uzyskał jeszcze kilka innych nadań na posiadłości królewskie. Oprócz starostw dubieńskiego ${ }^{14}$, tłumackiego ${ }^{15}$, urzędowskiego i korytnickiego miał jeszcze starostwo dymirskie w województwie kijowskim ${ }^{16}$. W ziemi halickiej użytkował $z$ żoną wsie królewskie Tarnowica Leśna, Tarnowica Polna, Weleśnica Górna ${ }^{17}$, Bratkowice, Kamienna, Weleśnica Dolna ${ }^{18}$,

„upadku” dwóch dożywoci, mają jeszcze prawo do sumy 25 tys. florenów, czyli połowy kwoty pożyczki udzielonej skarbowi państwa przez Teodora Denhoffa. W związku $z$ tym przyznano im prowizję w wysokości 2500 złp. Przeciętny roczny dochód ze starostwa urzędowskiego wynosił w 1765 r. 18254 złp. 10 gr. Kwotę tę pomniejszono o stałe wydatki ponoszone przez starostę (4239 złp. $17 \mathrm{gr}$ ) oraz o prowizję przyznana użytkownikom (2500 złp.). Kwartę w wysokości 2878 złp. 20 gr obliczono więc od kwoty 11515 złp. 23 gr. Ten sposób wyliczenia kwarty zapewniał Potockim dochód ze starostwa urzędowskiego w wysokości nie mniejszej niż 11134 złp. rocznie. Por. Lustracja starostwa urzędowskiego, AGAD, Metryka Koronna [dalej: MK], Lustracje, dz. XVIII, sygn. 42, s. 98-107. Podobnie wyglądała kwestia użytkowania starostwa korytnickiego (wsie Korytnica, Bednacze, Jugi, Kąty, Kupce, Odłogi, Ruda, Sakluki, Wola Korytnicka, 1970 złp. kwarty). $\mathrm{Na}$ dzierżawie tej również ciążył dług w wysokości 24 tys. florenów $z$ racji pożyczki udzielonej skarbowi państwa w 1663 r. przez Jana Henryka ab Alten Bokuma, który miał zostać spłacony przez „wytrzymanie” czterech dożywoci przez spadkobierców wierzyciela. Por. AGAD, MK, Lustracje, dz. XVIII, sygn. 14, s. 81. Co ciekawe, chociaż Jan Henryk ab Alten Bokum nie był bezpośrednim przodkiem ani Eustachego, ani Marianny, to użytkowali oni starostwo korytnickie na tych samych zasadach co Urzędów.

${ }^{14}$ W skład starostwa dubieńskiego wchodziło miasto Dubienka oraz wsie Berezowce, Kładniów, Starosiele, Strzelce i Uchanka. Kwartę z tego starostwa wyliczono na 5802 złp. 9 gr. Por. Lustracja starostwa dubieńskiego, AGAD, MK, Lustracje, dz. XVIII, sygn. 74, s. 182-185. Por. też Słownik Geograficzny Królestwa Polskiego i innych krajów słowiańskich [dalej: SGKP], red. B. Chlebowski, F. Sulimierski, W. Walewski, t. II, Warszawa 1881, s. 190.

15 Bogate starostwo tłumackie składało się z miasta Tłumacz oraz wsi Bortniki, Dolina, Gruszka, Jezierzany, Kaleńce, Nadorożna i Olesza. W 1747 r. Eustachy i Marianna Potoccy otrzymali również wójtostwo tłumackie, które obejmowało niewielka osiadłość w mieście oraz wieś Słobodkę. Kwarta ze starostwa wynosiła 6946 złp. 8 gr, a z wójtostwa 157 złp. 20 gr. Por. Lustracja starostwa tłumackiego, AGAD, MK, Lustracje, dz. XVIII, sygn. 56, s. 125-133. Por. też SGKP, t. XII, Warszawa 1892, s. 350; K. Cze meryńs ki, O dobrach koronnych byłej Rzeczypospolitej Polskiej, dział I, Lwów 1870, s. 241; T. Żychliński, op. cit., t. XIV, s. 63.

16 Starostwo dymirskie (miasto Dymir i wieś Kotiużyńce) opłacało 1949 złp. 25 gr kwarty. Por. SGKP, t. II, s. 249.

${ }_{17}$ Wsie te małżonkowie Potoccy otrzymali 1 X 1750 r. Opłacali z nich 958 złp. 25 gr kwarty. Por. Lustracja wsi Tarnowica Leśna, Tarnowica Polna, Weleśnica Górna, AGAD, MK, Lustracje, dz. XVIII, sygn. 74, s. 133-136.

$18 \mathrm{~W}$ posiadanie tych wiosek Eustachy i Marianna Potoccy weszli 1 XII 1756 r. Kwarta $\mathrm{z}$ tej dzierżawy została wyliczona na 1141 złp. 8 gr. Por. Lustracja wsi 
Hryniowce i Korolówka alias Durtów ${ }^{19}$. W tej samej ziemi miał jeszcze Targowicę, Słobodę i Zakrzewce ${ }^{20}$. W 1746 r. Eustachy Potocki wszedł też $\mathrm{z}$ żoną $\mathrm{w}$ posiadanie dzierżawy Paparzyn w województwie chełmińskim ${ }^{21}$. W 1757 r. otrzymał zaś nadanie królewskie na wieś Brzostówkę $\mathrm{w}$ województwie lubelskim ${ }^{22}$. Trzymał także przekazane mu przez ojca w 1738 r. wsie Chreptyjów, Dziurdzianka i Dankowce na Podolu, a w latach 1764-1767 był też starosta lwowskim ${ }^{23}$. Suma kwarty $z$ posiadanych przez niego dóbr domeny wynosiła (według taryfy z 1771 r.) 25690 złp. Oznacza to, że dobra te przynosiły mu przynajmniej 150 tys. złp. rocznego docho$\mathrm{du}^{24}$. W 1747 r. zmarł ojciec Eustachego Potockiego. Ten ostatni wszedł wówczas w posiadanie klucza syrnickiego w województwie lubelskim, Horodyszcza z przyległościami w województwie brzeskolitewskim oraz wsi Palaicze, Łokutka i Susz w ziemi halickiejej. Być może otrzymał też jakieś niewielkie udziały w kluczu podhajeckim

Bratkowice, Kamienna, Weleśnica Dolna, AGAD, MK, Lustracje, dz. XVIII, sygn. 74, s. $136-138$.

19 August III nadał tę królewszczyznę Potockim 1 X 1761 r. Opłacali z niej 1028 złp. 1 gr kwarty. Por. Lustracja wsi Hryniowce i Korolówka alias Durtów, AGAD, MK, Lustracje, dz. XVIII, sygn. 74, s. 138-140.

20 Por. AGAD, APR nr 161 (Akta procesowe E. Potockiego ze Stanisławem Potockim, wojewoda poznańskim o posiadanie królewszczyzny Bratkowice, Kamienna, Targowica, Tarnawica Leśna i Polna, Weleśnica Dolna, Słoboda i Zakrzewce).

${ }^{21} \mathrm{~W}$ istocie Potoccy otrzymali Paparzyn w ramach wymiany za dzierżawione przez nich wcześniej dobra królewskie Pruszewo i Bzynno, które przekazali dotychczasowemu dzierżawcy Paparzyna. Por. AGAD, APR nr 166 (Akta Eustachego Potockiego, dotyczące dzierżawy królewszczyzn Pruszewo i Bzynno oraz zamiany ich na królewszczyznę Paparzyn z przyległościami „województwo chełmińskie”).

${ }^{22}$ Barbara Grosfeld błędnie podała, że Eustachy Potocki nabył Brzostówkę na własność. Por. e a dem, op. cit., s. 806. W istocie była to królewszczyzna, z której Potoccy płacili 304 złp. 15 gr kwarty. Por. Lustracja wsi Brzostówki, AGAD, MK, Lustracje, dz. XVIII, sygn. 42, s. 76-80.

${ }^{23}$ Por. B. Grosfeld, op. cit., s. 806.

${ }^{24}$ Por. T. Zi elińs ka, Magnateria polska epoki saskiej. Funkcje urzędów i królewszczyzn $w$ procesie przeobrażeń warstwy społecznej, Wrocław 1977, s. 114, 120, 127, 140; B. Grosfeld, op. cit., s. 806. Warto w tym miejscu zaznaczyć, że lustracja królewszczyzn $z$ lat 1764/1765 przyniosła niemal dziesięciokrotne zwiększenie wymiaru kwarty. Według szacunków króla Stanisława Augusta Poniatowskiego jej wymiar oparty był jednak na trzykrotnie, jeśli nie pięciokrotnie zaniżonej intracie $z$ dóbr domeny. Por. T. Zielińs ka, op. cit., s. 91. W moim przekonaniu obliczenia intraty dóbr królewskich dokonane przez lustratorów nie były aż tak zaniżone i w związku $z$ tym mnożę czysty dochód $z$ dzierżaw Eustachego Potockiego jedynie przez dwa - (25 690 × $3=77$ 070) x $2=154140$.

${ }^{25}$ Wszystkie te posiadłości zostały uwzględnione w spisie dóbr, które pozostały po Eustachym i Mariannie $z$ Katskich Potockich. 
(miasto i zamek Podhajce odziedziczył jego młodszy brat Marian, starosta grabowiecki) ${ }^{26}$. Nie zmieniło to jednak w sposób istotny sytuacji majatkowej Eustachego i Marianny Potockich. Zasadniczy trzon ich posiadłości stanowiły bowiem dobra odziedziczone po Kątskich i Szczukach.

Małżonkowie Potoccy dysponowali naprawdę dużym majątkiem. Eustachy uważany był za czwartego co do zamożności przedstawiciela swojego rodu. Bogatsi od niego byli jedynie hetman wielki koronny Józef (zm. 1751), później zaś jego syn, wojewoda poznański Stanisław (zm. 1760), wojewoda kijowski Franciszek Salezy (zm. 1772) oraz starosta kaniowski Mikołaj Bazyli (zm. 1782). Roczny dochód Eustachego ( $z$ dóbr dziedzicznych i królewszczyzn) szacowano na 40 tys. dukatów ${ }^{27}$. Dodajmy także, że Eustachy i Marianna Potoccy utrzymali w zasadzie w niezmienionej postaci swój stan posiadania. Z majątków odziedziczonych przez Mariannę sprzedali jedynie dobra Drozdowice w ziemi przemyskiej (dawna posiadłość Kątskich) oraz wsie Chorchówkę i Leśniówkę w powiecie bieckim, które pochodziły ze spadku po Stanisławie Antonim Szczuce $^{28}$. Eustachy Potocki kupił natomiast od swego brata Mariana wieś Kutyszcze $z$ klucza podhajeckiego. Nie utrzymał jej jednak w swoim ręku, gdyż w 1765 r. odsprzedał tę posiadłość Jakubowi Górskiemu ${ }^{29}$.

Duży majątek umożliwił Eustachemu Potockiemu czynne uczestnictwo w życiu publicznym Rzeczypospolitej. Związany, podobnie

${ }^{26}$ Por. W. Szczygiels ki, Potocki Marian, [w:] PSB, t. XXVIII, s. 94.

${ }^{27}$ Louis Adrien Duperron de Castéra, rezydent francuski w Warszawie, sporzadził w 1750 r. zestawienie rocznych dochodów najbogatszych przedstawicieli rodu Potockich. Jego zdaniem Józef Potocki, hetman wielki koronny, uzyskiwał ze swoich dóbr 180 tys. dukatów, Franciszek Salezy Potocki, wówczas krajczy koronny - 60 tys. dukatów, a Mikołaj Bazyli Potocki, starosta kaniowski - 50 tys. dukatów. Czwarte miejsce na tej liście zajmował Eustachy Potocki, starosta tłumacki, z dochodem rocznym 40 tys. dukatów. Warto dodać, że jedyny syn hetmana, Stanisław Potocki, podówczas wojewoda kijowski, dysponował za życia ojca dochodem rocznym w wysokości 24 tys. dukatów. Co zaś wydaje się w tym wszystkim najważniejsze, szacunki francuskiego dyplomaty sa bardzo zbliżone do rzeczywistości, o czym przekonuje zwłaszcza przykład Eustachego Potockiego. Por. K. Walis zew ski, Potoccy i Czartoryscy. Walka stronnictw i programów politycznych przed upadkiem Rzeczypospolitej 1734-1763, t. I (1734-1754), Kraków 1886, s. 18.

${ }^{28}$ Por. AGAD, APR nr 144 (Akta Marianny z Katskich Eustachowej Potockiej, dotyczące dóbr Chorchówka i Leśniówka „powiat biecki”); nr 148 (Akta sprzedaży dóbr Drozdowice $z$ przyległościami „ziemia przemyska”).

${ }^{29}$ Por. AGAD, APR nr 158 (Akta Eustachego Potockiego dotyczące sprzedaży dóbr Kutyszcze Jakubowi Górskiemu „ziemia halicka”). 
jak większość członków rodziny Potockich, ze stronnictwem republikantów zorientowanym na Francję, nie odegrał jednak poważniejszej roli politycznej. Nie wszedł też do senatu, zadowalając się dygnitarstwami - cześnikostwem koronnym (nominacja 6 lipca 1754 r.), a następnie generalstwem artylerii litewskiej (nominacja 20 października 1759 r.). Ostatnie lata życia spędził w Radzyniu, gdzie według planów Jakuba Fontany i pod jego kierownictwem wybudował wspaniały pałac $z$ ogrodem. Rozległe zainteresowania kulturalne generała artylerii litewskiej podzielała również jego małżonka. Wyrazem pasji literackich Marianny z Kątskich Potockiej stały się m.in. jej amatorskie przekłady na język polski niektórych utworów Moliera ${ }^{30}$. Szczęśliwe pożycie małżeńskie Eustachego i Marianny zakończyła nagła i niespodziewana śmierć generałowej artylerii litewskiej, która zmarła 20 lutego 1768 r. Trzy dni później, 23 lutego, sporządziwszy wcześniej testament, odszedł również Eustachy Potocki ${ }^{31}$.

W chwili śmierci Eustachego i Marianny z Katskich Potockich ich latyfundium obejmowało majątki: klucz sartawicki w powiecie świeckim (województwo pomorskie) ${ }^{32}$, klucz szczuczyński w ziemi wiskiej (województwo mazowieckie), wsie Turna i Chmielów w ziemi liwskiej (województwo mazowieckie), klucz Wysokie Mazowieckie w powiecie drohickim (województwo podlaskie), „hrabstwo” sidrzańskie w powiecie grodzieńskim (województwo trockie), klucz horodyski w powiecie brzeskim (województwo brzeskolitewskie), klucz kurowski, klucz radzyński, klucz syrnicki, klucz biłgorajski ${ }^{33}$

${ }^{30}$ Więcej o działalności politycznej Eustachego Potockiego oraz zainteresowaniach kulturalnych małżonków Potockich por. B. Grosfeld, op. cit., passim; B. Michalik, Działalność oświatowa Ignacego Potockiego, Wrocław 1979, s. 20; J. Kowalik, Maria $z$ Katskich Potocka (ok. 1720-1768): przyczynek do życia kulturalnego w Radzyniu w II połowie XVIII wieku, „Radzyński Rocznik Humanistyczny" 2001, t. I, s. 35-46; Z. J a n e czek, Korespondencja Marianny z Kątskich Potockiej $z$ komendantem twierdz ukrainnych generałem Joachimem Potockim, $z$ lat 1756-1760, [w:] Ród Potockich w odmęcie historii (XVII-XX wiek), red. Z. Janeczek, Katowice 2007, s. 403-452; K. Go m bin, Inicjatywy artystyczne Eustachego Potockiego, Lublin 2009.

${ }^{31}$ Por. T. Żychliński, op. cit., t. I, tabl. 3; L. Bożawola-Romanowski, Rodowód Potockich hrabiów herbu Pilawa. $Z$ podań historycznych, $z$ autentyków, pamiętników rodzinnych, monografii i długoletnich własnych studiów zebrany, Warszawa 1882, nr 129; B. Gros feld, op. cit., s. 806.

${ }^{32}$ Sartawice $z$ przyległościami kupił Stanisław Antoni Szczuka w 1686 r. od Andrzeja Wierzbowskiego, wojewodzica brzesko-kujawskiego. Por. SGKP, t. X, Warszawa 1889 , s. 327.

${ }^{33}$ Miasto Biłgoraj z przyległymi wsiami zakupił od spadkobierców Gorajskich Stanisław Antoni Szczuka. Por. SGKP, t. I, Warszawa 1880, s. 227. 
w województwie lubelskim, wieś Truszowice w ziemi przemyskiej (województwo ruskie), klucz budzanowski z wsią Zwiniacz oraz wsie Palaicze, Łokutka i Susz w ziemi halickiej (województwo ruskie), klucze hornostajpolski, borodziański i kozarowicki ${ }^{34}$ w województwie kijowskim oraz klucz krzywiecki z wsią Babińce, jak również wsie Neteczyńce Stare, Neteczyńce Nowe, Daszkowce i Zeniszkowce w województwie podolskim. Eustachy i Marianna Potoccy byli właścicielami 11 miast, 104 wsi całych, dwóch części wsi, 25 folwarków, czterech jurydyk miejskich, pałacu i dworku w Warszawie, dworku na Pradze, pałacu w Lublinie oraz kamienic w Lublinie i Kamieńcu Podolskim. Należące do nich dobra alodialne przynosiły ponad 460 tys. złp. rocznego dochodu ${ }^{35}$.

Małżonkowie Potoccy pozostawili po sobie liczne potomstwo. Ich synami byli: Kajetan (ok. 1749-1802), Ignacy (1750-1809), Jerzy Michał (1753-ok. 1801), Stanisław Kostka (1754-1826) oraz Jan Nepomucen Eryk (1761-po 1815). Spośród nich zwłaszcza Ignacy i Stanisław Kostka zapisali się na trwałe w dziejach Rzeczypospolitej ${ }^{36}$. Jedyna córka Eustachego i Marianny, Cecylia Urszula (1747-1771), najstarsza $z$ rodzeństwa, 2 lutego 1767 r. poślubiła w Lublinie starostę czerkaskiego księcia Hieronima Sanguszkę (1743-1812), który w przyszłości został wojewoda wołyńskim ${ }^{37}$. W obliczu śmierci żony i własnej choroby Eustachy Potocki zamie-

${ }^{34}$ Borodziankę, Hornostajpol i Kozarowicze Stanisław Antoni Szczuka nabył od spadkobierców Andrzeja Drohojowskiego. Por. SGKP, t. I, s. 316, t. III, Warszawa 1882, s. 130.

${ }^{35}$ Por. Kopia testamentu Eustachego Potockiego i transakcji rozdziału dóbr między jego synów z roku 1771, AGAD, Archiwum Publiczne Potockich [dalej: APP] nr 374, s. 10-38, 42.

${ }^{36}$ Bliższe informacje dotyczace synów Eustachego i Marianny z Kątskich Potockich oraz zestawienie poświęconej im literatury przedmiotu por. Z. Zi elińs ka, Potocki Roman Ignacy Franciszek, [w:] PSB, t. XXVIII, s. 1-17; eade m, Potocki Jan Nepomucen Eryk, [w:] ibidem, s. 42-43; Z. A nu sik, Potocki Jerzy Michat, [w:] ibidem, s. 44-47; B. G r o chuls ka, Potocki Stanisław Kostka, [w:] ibidem, s. 158170. Por. też Z. Anusik, Zapomniany potomek sławnego rodu - Kajetan Potocki (zm. 1802), starosta urzędowski, dymirski i korytnicki [w druku].

37 Cecylia Urszula była jedyna córka Eustachego i Marianny z Kątskich Potockich. Nie ma więc racji Włodzimierz Dworzaczek, który przypisał generałowi artylerii litewskiej jeszcze jedna córkę - Laurę, żonę Stanisława Tarnowskiego. Por. idem, op. cit., t. II, tabl. 141. Błą ten powieliła również B. Grosfeld. Por. e a d e m, op. cit., s. 806. W rzeczywistości Laura Potocka była wnuczką Eustachego, córka jego najmłodszego syna Jana Nepomucena Eryka. Por. Z. Zielińs ka, Potocki Jan Nepomucen..., s. 43. Więcej informacji o mężu Cecylii Urszuli Potockiej por. E. Orma n, Sanguszko Hieronim Janusz, [w:] PSB, t. XXXIV, Wrocław-Warszawa-Kraków 1992-1993, s. 484-488. 
rzał przekazać najstarszemu synowi jakąś część posiadanych przez siebie królewszczyzn. Nie zdążył jednak tego uczynić przed swoim nagłym zgonem. W sporządzonym w dniu 22 lutego testamencie, polecając swoje dzieci protekcji króla, opiekę nad nieletnimi synami (w lutym 1768 r. pełnoletni był jedynie Kajetan) ${ }^{38}$ generał artylerii litewskiej powierzył wojewodzie kijowskiemu Franciszkowi Salezemu Potockiemu, swojemu bratu Marianowi (zm. po 1777), eks-kasztelanowi lubaczowskiemu, Hieronimowi Wielopolskiemu (1712-1779), koniuszemu koronnemu, i jego żonie, Urszuli $z$ Potockich (1725-1806) oraz swojej siostrze, Katarzynie z Potockich Kossakowskiej (1722-1803), kasztelanowej kamieńskiej. Ta ostatnia została główną opiekunką młodych generałowiczów. Kossakowskiej zlecił bowiem Eustachy Potocki nadzór nad edukacją swoich synów, jak również troskę o zabezpieczenie ich interesów materialnych. Wyrazem tego była podjęta na łożu śmierci decyzja o wypuszczeniu kasztelanowej kamieńskiej w czteroletnią dzierżawę wszystkich dóbr ziemskich, które wchodziły w skład latyfundium należącego do niego oraz do jego zmarłej właśnie małżonki ${ }^{39}$.

Warto w tym miejscu zaznaczyć, że młodzi Potoccy utrzymali w swoim ręku część królewszczyzn użytkowanych przez ich rodziców. Wkrótce po śmierci ojca Kajetan Potocki otrzymał bowiem nadania na kilka trzymanych przez generała artylerii litewskiej dóbr domeny. Już 29 lutego 1768 r. król nadał Potockiemu starostwo dymirskie w województwie kijowskim (1949 złp. 25 gr kwarty $)^{40}$, wieś Brzostówkę w województwie lubelskim (304 złp. 15 gr kwarty) ${ }^{41}$ oraz wójtostwo i starostwo urzędowskie w tym samym województwie (2878 złp. 20 gr kwarty) ${ }^{42}$. Dnia 8 marca 1768 r. najstarszy z braci Potockich otrzymał nadanie dzierżawy korytnickiej

${ }^{38} \mathrm{~W}$ świetle prawa obowiązującego w dawnej Rzeczypospolitej pełna dojrzałość osiągał mężczyzna w wieku 24 lat. Niemniej jednak w czasach stanisławowskich za pełnoletnich uznawano młodzieńców, którzy ukończyli 18 rok życia. Tak było również w przypadku młodych Potockich, w wieku 18 lat uwalnianych $z$ opieki ciotki Kossakowskiej.

${ }^{39}$ Kopia testamentu Eustachego Potockiego..., AGAD, APP nr 374, s. 2-3.

40 Nadanie Kajetanowi Potockiemu starostwa dymirskiego, AGAD, MK, Sigillata, sygn. 33, s. 9. Por. też SGKP, t. II, s. 249.

${ }^{41}$ Nadanie Kajetanowi Potockiemu wsi Brzostówki, AGAD, MK, Sigillata, sygn. 33, s. 9. Por. też Lustracja wsi Brzostówki, AGAD, MK, Lustracje, dz. XVIII, sygn. 42 , s. $76-80$.

${ }^{42}$ Nadanie Kajetanowi Potockiemu wójtostwa urzędowskiego, AGAD, MK, Sigillata, sygn. 33, s. 9; Potwierdzenie praw Kajetana Potockiego do starostwa urzędowskiego, ibidem. Dodajmy, że Kajetan Potocki użytkował starostwo urzędowskie 
w ziemi liwskiej na Mazowszu (1790 złp. kwarty) ${ }^{43}$, a 12 marca król obdarował go jeszcze wójtostwem we wsi Brzostówka ${ }^{44}$. W sumie zatem w ręce Kajetana Potockiego trafiły dwa miasta, dwa wójtostwa i 13 wsi królewskich, z których opłacał on 6923 złp. kwarty. Oznacza to, że dzierżawione przez niego królewszczyzny przynosiły mu na pewno więcej niż 20 tys. złp. rocznego dochodu.

W 1771 r. trzej starsi generałowicze artylerii litewskiej przekroczyli już 18 rok życia i zostali uwolnieni $z$ opieki ciotki Kossakowskiej. Można więc było pomyśleć o wydzieleniu każdemu $z$ nich należnej mu części spadku. W dniu 17 lipca tego roku trzej starsi synowie Eustachego i Marianny $z$ Katskich Potockich podzielili się też w Warszawie ruchomościami pozostałymi po ich rodzicach ${ }^{45}$. Był to jednak jedynie wstęp do mającego wkrótce nastąpić rozdysponowania całej schedy. Dnia 26 listopada 1771 r. bracia Potoccy dokonali bowiem w stolicy podziału wszystkich dóbr nieruchomych pozostałych po generałostwie artylerii litewskiej. Bardzo istotna rolę $\mathrm{w}$ przeprowadzonych wówczas transakcjach majątkowych odegrała ich ciotka, Katarzyna Kossakowska, która w dalszym ciagu miała pozostać opiekunką dwóch najmłodszych synów Eustachego Potockiego. Ona też reprezentowała interesy Stanisława Kostki i Jana Nepomucena Eryka w transakcji podziałowej ${ }^{46}$. Dzieląc się majatkiem, trzej starsi generałowicze artylerii litewskiej skwitowali $z$ opieki kasztelanową kamieńską i, potwierdzając decyzję ojcowską z lutego 1768 r., powierzyli jej opiekę nad dobrami dwóch młodszych braci aż do czasu osiagnięcia przez nich pełnoletności ${ }^{47}$.

na tych samych zasadach co jego rodzice, opłacając $z$ niego w 1771 r. 2878 złp. 20 gr kwarty. Por. SGKP, t. XII, s. 827.

${ }^{43}$ Potwierdzenie praw Kajetana Potockiego do dzierżawy korytnickiej, AGAD, MK, Sigillata, sygn. 33, s. 11. Por. też SGKP, t. IV, Warszawa 1883, s. 428.

${ }^{44}$ Nadanie Kajetanowi Potockiemu wójtostwa we wsi Brzostówka, AGAD, MK, Sigillata, sygn. 33, s. 12.

${ }^{45}$ Kopia testamentu Eustachego Potockiego..., AGAD, APP nr 374, s. 50.

46 Podziału majątku dokonano według powszechnie przyjętych w Rzeczypospolitej zwyczajów. Spadkobiercy podzielili dobra na pięć równych części, po czym rozpoczęto wybór sched, zaczynajac od najmłodszego sukcesora. W imieniu Jana i Stanisława Kostki wyboru dokonała Katarzyna Kossakowska. Wybrała też dla swoich podopiecznych dobra najmniej obciążone różnego rodzaju zobowiązaniami. Dodajmy także, że jedyna córka Eustachostwa Potockich miała prawo do szóstej części dóbr po matce i czwartej części dóbr po ojcu. Ostatecznie jednak księżna Sanguszkowa zrezygnowała ze swojego udziału w spadku po rodzicach, zadowalając się wypłata posagu.

${ }^{47}$ Kopia testamentu Eustachego Potockiego..., AGAD, APP nr 374, s. 8. 
Dobra ziemskie wchodzace w skład ogromnego latyfundium należącego niegdyś do Eustachego i Marianny $z$ Katskich Potockich przynosiły 460392 złp. 22 gr rocznego dochodu. Odpowiadało to ich wartości szacunkowej przekraczającej $9 \mathrm{mln} 200$ tys. złp. Ponieważ jednak różnego rodzaju zobowiązania ciążące na tych dobrach pochłaniały 64405 złp. 9 gr rocznie, podziału dokonano, biorac za podstawę jedynie $396187 \mathrm{złp} .13$ gr czystego rocznego dochodu $z$ tych majątków. W myśl ugody działowej każdy ze spadkobierców otrzymał dobra przynoszące 79237 złp. 14 gr rocznego dochodu netto ${ }^{48}$.

Najstarszy $z$ braci - Kajetan Potocki wziął klucz radzyński w województwie lubelskim (miasto Radzyń, wsie Głowna, Kozi Rynek, Lichty, Lisia Wólka, Oprawy, Płudy, Rabsztyn, Wrzosów, Zabiele, Zbilitów, folwarki Bezwola, Biała, Białka, Branica, Chomiejowa Wola, Niewęgłowski, Siedlanów, Ustrzeż), klucz horodyski w województwie brzeskolitewskim (miasto Horodyszcze $z$ wsiami Dubice i Polubicze), wsie Turnę i Chmielów w ziemi liwskiej na Mazowszu oraz jurydykę Tłumackie w Warszawie (łącznie dwie miasta, 14 wsi, osiem folwarków i jurydyka miejska). Roczny dochód $z$ tych majątków wyliczono na 95175 złp. 29 gr $^{49}$.

Drugi z braci - Ignacy otrzymał klucz kurowski (miasto Kurów, wsie Abrahamów, Brzozowa, Gać, Glinnik, Os, Paluchów, Płonki, Szumów, Wolica I, Wolica II „połowa”, folwarki Dembiany, Jenopol, Klimontowice, Wielki Las, Wielkie Zabuże) i klucz syrnicki (wsie Syrniki, Chlewiska, Pałecznica, Ruska Wola, Stańkowa Wola, Wola Syrnicka, folwarki Czerniejowski, Zabłocka Wólka) w województwie lubelskim, klucz sartawicki (wsie Sartawice Dolne, Sartawice Górne [dziś Sartowice], Czaple Małe, Czaple Wielkie, Dziki, Kępa Sartawicka, Michale, Mniszek, Nowe Marze [dziś Nowe Marzy], Puskawice, Stare Marze, Święte Małe, Święte Wielkie) w województwie pomorskim oraz jurydykę Mariensztat w Warszawie, dworek na Pradze $z$ łaźnią i pałac w Warszawie wraz $z$ całym wyposażeniem (łącznie jedno miasto, 28 wsi całych, jedna część wsi, siedem folwarków, jurydyka miejska). Dobra te przynosiły 107581 złp. 5 gr rocznego dochodu ${ }^{50}$.

\footnotetext{
48 Por. ibidem, s. 42.

49 Por. ibidem, s. 36-38.

50 Por. ibidem, s. 29-31.
} 
Trzeci $z$ synów Eustachego Potockiego - Jerzy Michał wzią hrabstwo sidrzańskie w województwie trockim (miasto Sidra, wsie Berwicha, Burniki, Czerepczyce, Dołhozieki, Lisionory, Mieleńkowce, Nowosiółka, Putnowce, Siekirka, Staworów, Stomianka, Wyżgi, folwarki Jałowski, Krzysztoforowski, Kuziński, Makowlański, Mikliewski, Mozciszański, Poturbowski, Wólczański), klucz szczuczyński w województwie mazowieckim (miasta Szczuczyn i Ossowiec, wsie Barany, Chojnowo, Ciemianka, Czarnówek, Glinki, Grabowy, Jambrzyki, Pełczyn, Skacie, Szymany, Wólka, folwarki Ławski, Słucz), miasto Wysokie Mazowieckie $z$ wsiami Mścichy, Osipy i Zawrotna w województwie podlaskim, jurydykę w Grodnie nad Niemnem i druga nad Horodnica, spichlerze w Ossowcu i Grodnie oraz pięć szkut zbożowych na Biebrzy (łącznie cztery miasta, 26 wsi, dziesięć folwarków, dwie jurydyki miejskie). Roczny dochód brutto $z$ tych majętności został wyliczony na 86541 złp. 20 gr $^{51}$.

Czwarta scheda przypadła w udziale Stanisławowi Kostce Potockiemu. Składały się na nią klucz budzanowski (miasto Budzanów, wsie Laskowce, Kossów i Wierzbowce), klucz krzywiecki (miasto Krzywcze $z$ przedmieściami, wsie Chodyjowce (część) i Filipkowce) oraz wsie Babińce, Daszkowce, Neteczyńce Stare, Neteczyńce Nowe, Zeniszkowce, Palaicze, Łokutka, Susz oraz Zwiniacz (łacznie dwa miasta, 13 wsi całych, jedna część wsi). Dobra te przynosiły rocznie dochód w wysokości 84117 złp 1,5 gr52.

Najmłodszy z braci Potockich - Jan Nepomucen Eryk otrzymał w dziale klucz biłgorajski w województwie lubelskim (miasto Biłgoraj, wsie Cecylopol, Dobrowola, Dyle, Ignatówka, Kajetanówka, Rapy), w województwie kijowskim klucz borodziański (wsie Borodzianka, Drużanka, Nowa Grobla, Piaskówka, Zahale), klucz hornostajpolski (miasto Hornostajpol, wsie Bohdany, Demontów, Dydziatki, Łaputki, Pilawa, Ruchtycze, Stracholice, Suchotacze), klucz kozarowicki (wsie Kozarowicze, Chlibówka, Jasnohrodka), wieś Truszowice $\mathrm{w}$ województwie ruskim, pałac w Lublinie, spalona kamienice $\mathrm{w}$ tym samym mieście oraz kamienicę w Kamieńcu Podolskim (łącznie dwa miasta 23 wsie). Roczny dochód $z$ tych majątków wyliczono na 87176 złp. 26 gr brutto ${ }^{53}$.

\footnotetext{
51 Por. ibidem, s. 21-23.

52 Por. ibidem, s. 14-16.

53 Por. ibidem, s. $10-11$.
} 
Warto jednak zaznaczyć, że na dobrach wchodzacych w skład każdej z pięciu sched ciążyły różnego rodzaju zobowiązania na rzecz osób i instytucji, tak świeckich, jak i kościelnych. Były to sumy znaczacce, w przypadku trzech starszych generałowiczów przekraczające kwotę 15 tys. złp. Aby wyliczyć dochód netto $z$ dóbr każdego $z$ braci, należało zatem dokonać zestawienia przychodów brutto $z$ suma stałych wydatków rocznych na pokrycie bieżacych oraz zaciagniętych wcześniej zobowiązań. W przypadku Kajetana Potockiego było to 95175 złp. 29 gr przychodu i 17733 złp. 17 gr zobowiązań. Dochód netto ze schedy najstarszego $z$ generałowiczów wynosił więc 77442 złp. 11 gr. Ignacy Potocki miał 107581 złp. 5 gr przychodu brutto. Zobowiązania ciażące na jego dziale majątkowym pochłaniały 15217 złp. 5 gr rocznie. Jego dochód netto wyliczono zatem na 92364 złp. W odniesieniu do działu Jerzego Michała było to 86541 złp. 20 gr przychodu brutto, 15878 złp. 16 gr obciążeń i 70663 złp. 4 gr dochodu netto. Dział Stanisława Kostki przynosił 84117 złp. rocznie, a obciażenia pochłaniały 11789 złp. Dochód netto dla tej schedy wyliczono na 72328 złp. 1 gr. Dobra, które przeznaczono dla Jana Nepomucena Eryka, przynosiły z kolei 87176 złp. 26 gr rocznego dochodu brutto, a ciążyły na nich zobowiazania, które pochłaniały jedynie $3787 \mathrm{złp}$. W tej sytuacji dochód roczny netto $z$ tych majątków obliczono na 83389 złp. 26 gr $^{54}$. Ażeby uzyskać przyjęta za podstawę działów kwotę 79237 złp. 14 gr rocznego dochodu netto, dla każdego ze spadkobierców ustalono, że właściciel największego działu - Ignacy wypłacać będzie w czerwcu każdego roku kwote 1795 złp. 3 gr Kajetanowi, 8574 złp. 10 gr Jerzemu Michałowi i 2757 złp. 2 gr Stanisławowi Kostce. Ten ostatni otrzymywać miał również w tym samym terminie $4152 \mathrm{złp} .11 \mathrm{gr}$ $z$ majątków, które przypadły w udziale najmłodszemu $z$ braci ${ }^{55}$.

Podzieliwszy między siebie majątek nieruchomy, 15 grudnia 1771 r. bracia Potoccy zajęli się także podziałem ruchomości ze skarbca pałacu radzyńskiego ${ }^{56}$. Zakończenie tych długich i skomplikowanych transakcji majątkowych między spadkobiercami Eustachego i Marianny Potockich nastapiło jednak dopiero w dniu 10 marca 1772 r., gdy Kajetan, Ignacy i Jerzy Michał Potoccy raz jeszcze skwitowali $z$ opieki Katarzynę Kossakowską i dokonali rozliczenia wzajemnych pretensji majątkowych za okres od 26 listopada

\footnotetext{
${ }^{54}$ Por. ibidem, s. 42.

55 Por. ibidem.

${ }^{56}$ Por. ibidem, s. 75.
} 
1771 r. do 22 lutego 1772 r. W tym samym dniu Ignacy i Jerzy Michał poręczyli też pożyczki, jakie Kajetan Potocki zaciągnął na wypłacenie posagu nieżyjącej już siostry (zm. 12 grudnia 1771 r.) Cecylii Urszuli ks. Sanguszkowej ${ }^{57}$.

Wbrew pozorom podjęte w marcu 1772 r. ustalenia nie zakończyły bynajmniej rozliczeń między braćmi Potockimi. Jeszcze $\mathrm{w}$ listopadzie $1771 \mathrm{r}$. zapowiedziano bowiem generalny i tym razem już ostateczny dział majątkowy po osiągnięciu pełnoletności przez Stanisława Kostkę i Jana Nepomucena Eryka ${ }^{58}$. Na razie jednak Kajetan, Ignacy i Jerzy Michał Potoccy mogli korzystać, aczkolwiek $z$ pewnymi ograniczeniami (nie mogli otrzymanych dóbr sprzedać, zastawić ani obciążyć nowymi długami), $z$ odziedziczonych po rodzicach zasobów majątkowych. Wkraczając w samodzielne życie, każdy z nich był właścicielem dóbr ziemskich, których wartość szacunkowa przekraczała $1,8 \mathrm{mln}$ złp. Nie były to oczywiście majątki na miare pierwszych fortun magnackich w Rzeczypospolitej. O ile bowiem Eustachy Potocki zaliczany był do grona najbogatszych przedstawicieli swojego rodu, to już jego synowie uważani byli za uboższych członków rodziny Potockich. Niemniej jednak posiadane zasoby majątkowe czyniły $z$ braci Potockich ludzi zamożnych. Zarówno Kajetan, starosta dymirski, urzędowski i korytnicki, jak i Jerzy Michał, starosta tłumacki, $z$ pewnościa dysponowali dochodami przekraczajacymi kwotę 100 tys. złp. rocznie. Dodajmy tylko w tym miejscu, że w 1779 r. synowie Eustachego i Marianny z Kątskich Potockich dokonali kolejnego, tym razem już ostatecznego podziału dóbr po rodzicach, zmieniając diametralnie postanowienia transakcji podziałowej z 1771 r. Ponieważ zaś żaden $z$ nich nie okazał się dobrym gospodarzem, wkrótce rozpoczęli stopniowa wyprzedaż odziedziczonych po przodkach majątków. Jest to jednak problem zasługujący na odrębne opracowanie.

57 Por. Kopia transakcji między Katarzyna z Potockich Kossakowska, kasztelanową kamieńską z jednej, a Kajetanem, starostą urzędowskim, Ignacym i Jerzym, starosta tłumackim Potockimi $z$ drugiej strony spisanych $\mathrm{w}$ Warszawie dnia 10 marca 1772 r., ibidem, s. 96-97.

58 Por. Kopia testamentu..., AGAD, APP nr 374, s. 43. 


\section{Bibliografia}

\section{ŹRódeA ARChIWALNe}

Archiwum Główne Akt Dawnych [AGAD]

Archiwum Potockich $z$ Radzynia [APR]

nr $12,13,14,15,19,25,26,33,34,35,37,144,148,153,154,155,158$, $161,163,166,169$.

Archiwum Publiczne Potockich [APP]

nr 374.

Metryka Koronna [MK]

Lustracje, dz. XVIII, sygn. 14, 42, 56, 74.

Sigillata, sygn. 33.

Zbiór Aleksandra Czołowskiego, sygn. 643.

\section{Opracowania}

Anusik Z., Potocki Jerzy Michat, [w:] Polski słownik biograficzny, t. XXVIII, Wrocław 1984-1985, s. 44-47.

Anusik Z., Zapomniany potomek sławnego rodu-Kajetan Potocki (zm. 1802), starosta urzędowski, dymirski i korytnicki [w druku].

Bożawola-Romanowski L., Rodowód Potockich hrabiów herbu Pilawa. $Z$ podań historycznych, $z$ autentyków, pamiętników rodzinnych, monografii i długoletnich własnych studiów zebrany, Warszawa 1882.

Czemeryński K., O dobrach koronnych byłej Rzeczypospolitej Polskiej, dział I, Lwów 1870.

Demidowicz T., Horodyszcze - zarys dziejów, Biała Podlaska 1996.

Dworzaczek W., Genealogia, t. II (Tablice), Warszawa 1959.

Dymnicka-Wołoszyńska H., Potocki Joachim, [w:] Polski słownik biograficzny, t. XXVIII, Wrocław 1984-1985, s. 50-51.

Gierowski J., Humiecki Stefan, [w:] Polski słownik biograficzny, t. X, WrocławWarszawa-Kraków 1962-1964, s. 100-102.

Gombin K., Inicjatywy artystyczne Eustachego Potockiego, Lublin 2009.

Grochulska B., Potocki Stanisław Kostka, [w:] Polski słownik biograficzny, t. XXVIII, Wrocław 1984-1985, s. 158-170.

Grosfeld B., Potocki Eustachy, [w:] Polski słownik biograficzny, t. XXVII, Wrocław 1983, s. 804-807.

Janeczek Z., Korespondencja Marianny $z$ Katskich Potockiej $z$ komendantem twierdz ukrainnych generałem Joachimem Potockim, z lat 1756-1760, [w:] Ród Potockich w odmęcie historii (XVII-XX wiek), red. Z. Janeczek, Katowice 2007, s. 403-452.

Keckowa A., Kotowski (pierwotne nazwisko Kot) Adam, [w:] Polski słownik biograficzny, t. XIV, Wrocław-Warszawa-Kraków 1968-1969, s. 488. 
Kobierecki M., Dzieje Kutna i okolicznych wsi w XVII i XVIII wieku, [w:] Kutno poprzez wieki, t. I (Do 1939 roku), red. J. Szymczak, Kutno-Łódź 2011, s. 177-216.

Konopczyński W., Cetner Jan, [w:] Polski słownik biograficzny, t. III, Kraków 1937, s. 240.

Kossakowski S.K., Monografie historyczno-genealogiczne niektórych rodzin polskich, t. II, Warszawa 1860.

Kowalik J., Maria $z$ Katskich Potocka (ok. 1720-1768): przyczynek do życia kulturalnego $w$ Radzyniu $w$ II połowie XVIII wieku, „Radzyński Rocznik Humanistyczny" 2001, t. I, s. 35-46.

Link-Lenczowski A., Potocki Józef Felicjan, [w:] Polski słownik biograficzny, t. XXVIII, Wrocław 1984-1985, s. 58-59.

Link-Lenczowski A., Potocki Stanisław Władysław, [w:] Polski słownik biograficzny, t. XXVIII, Wrocław 1984-1985, s. 154-156.

Link-Lenczowski A., Szklarska E., Potocki Michał, [w:] Polski słownik biograficzny, t. XXVIII, Wrocław 1984-1985, s. 97-101.

Michalik B., Działalność oświatowa Ignacego Potockiego, Wrocław 1979.

Niesiecki K., Herbarz polski, wyd. J.N. Bobrowicz, t. VII, Lipsk 1841.

Orman E., Sanguszko Hieronim Janusz, [w:] Polski słownik biograficzny, t. XXXIV, Wrocław-Warszawa-Kraków 1992-1993, s. 484-488.

Palkij H., Szczuka Stanisław Antoni, [w:] Polski słownik biograficzny, t. XLVII, Warszawa-Kraków 2010-2011, s. 469-481.

Przyboś A., Katski (Kacki, Kontski) Marcin Kazimierz, [w:] Polski słownik biograficzny, t. XII, Wrocław-Warszawa-Kraków 1967-1968, s. 316-319.

Przyboś A., Potocki Feliks Kazimierz, [w:] Polski słownik biograficzny, t. XXVII, Wrocław 1983, s. 807-812.

Przyboś A., Potocki Stanisław zwany Rewera, [w:] Polski słownik biograficzny, t. XXVIII, Wrocław 1984-1985, s. 140-151.

Rabowicz E., Stok P., Kątski Jan Stanisław, [w:] Polski słownik biograficzny, t. XII, Wrocław-Warszawa-Kraków 1967-1968, s. 314-315.

Słownik Geograficzny Królestwa Polskiego i innych krajów słowiańskich, red. B. Chlebowski, F. Sulimierski, W. Walewski, t. I, Warszawa 1880; t. II, Warszawa 1881; t. III, Warszawa 1882; t. IV, Warszawa 1883; t. X, Warszawa 1889; t. XII, Warszawa 1892.

Szczygielski W., Potocki Marian, [w:] Polski słownik biograficzny, t. XXVIII, Wrocław 1984-1985, s. 94-96.

Uruski S., Kosiński A.A., Włodarski A., Rodzina. Herbarz szlachty polskiej, t. XIV, Warszawa 1917.

Waliszewski K., Potoccy i Czartoryscy. Walka stronnictw i programów politycznych przed upadkiem Rzeczypospolitej 1734-1763, t. I (1734-1754), Kraków 1886.

Zielińska T., Magnateria polska epoki saskiej. Funkcje urzędów i królewszczyzn w procesie przeobrażeń warstwy społecznej, Wrocław 1977.

Zielińska Z., Potocki Jan Nepomucen Eryk, [w:] Polski słownik biograficzny, t. XXVIII, Wrocław 1984-1985, s. 42-43. 
Zielińska Z., Potocki Roman Ignacy Franciszek, [w:] Polski słownik biograficzny, t. XXVIII, Wrocław 1984-1985, s. 1-17.

Żychliński T., Złota księga szlachty polskiej, t. I, Poznań 1879; t. XIV, Poznań 1892.

ZBigniew Anusik

\title{
Division of the latifundium of Eustachy and Marianna née Kątska Potocki in $\mathbf{1 7 7 1}$
}

\begin{abstract}
$\mathrm{T}^{\mathrm{s}}$
he article is dedicated to the process of forming a latifundium which was in the possession of Eustachy Potocki and his wife, Marianna née Katska. Its creator was the Lithuanian sub-chancellor Stanisław Antoni Szczuka (died 1710). The property complex also included landed estates owned by Marcin (died 1710) and Jan Stanisław (died 1727) Kątski as well as Jerzy Potocki (died 1747). In total, Eustachy and Marianna Potocki were the owners of 11 cities, over 100 villages and 25 manors. These estates brought 460,000 Polish zlotys of annual income. After the deaths of both spouses in February 1768, their latifundium was divided among their five sons. The act of division was written in Warsaw in November 1771. Each of the heirs inherited landed estates bringing about 80,000 Polish zlotys net annual income. The division of the former latifundium of Eustachy and Marianna Potocki caused that their sons fell to the rank of poorer members of the Potocki family.
\end{abstract}

Keywords: latifundium, Potocki family, Polish magnates in $18^{\text {th }}$ century, division of landed estates of Eustachy and Marianna Potocki. 